Bruno Ganz, actor que encarna a Adolf Hitler en la cinta alemana La caída (Der untergang, 2004), es inmensamente popular. La nominación de la película al Óscar y su aclamada interpretación bastarían para explicarlo, pero la causa más importante de su reconocimiento, según admite el propio actor, es su meme. ${ }^{1}$

Los memes son los genes de la cultura. Fueron introducidos en el argot académico por el biólogo Richard Dawkins (El gen egoísta, 1976) para describir las unidades de transmisión que se difunden, como los genes, por copia o imitación. El contenido que transportan, en estos casos, es cultural. Siguiendo la analogía genética, son creados por usuarios y compiten por imponer sus códigos y esparcirlos en entornos virtuales. Los memes pueden ser ideas, símbolos o prácticas que se reproducen en diversos formatos y logran, si son exitosos, gran penetración en la red (Shifman 2012: 188-189)

Desde la creación de YouTube, el 2005, existen miles de famosos memes que toman películas como materia prima de su "genética". Uno de los que más versiones tiene es la escena clímax de La caída, cuando el líder nazi - encarnado por el popular Ganz- es informado de la inminente llegada de las tropas soviéticas a Berlín. La dinámica de este meme consiste en añadir al audio original en alemán, subtítulos apócrifos que hacen al personaje opinar sobre temas tan ajenos como el desempeño de la selección peruana de fútbol, los fallos del último invento de Apple, entre otros menos imaginables asuntos de la vida cotidiana.

Es difícil comprender este fenómeno fuera del marco de lo que Henry Jenkins ha llamado "cultura participativa". Esta es una característica distintiva de los nuevos medios, por la facilidad con que permite a los usuarios crear y recrear nuevos productos (de ahí el concepto de prosumidores). Se instala, con esta participación militante, un proceso cíclico de apropiación de las imágenes bajo la clave "hágalo usted mismo". Si se graban cortometrajes en un teléfono celular, con la misma facilidad se editan películas y se rehacen escenas. Todo es tecnológicamente posible. 


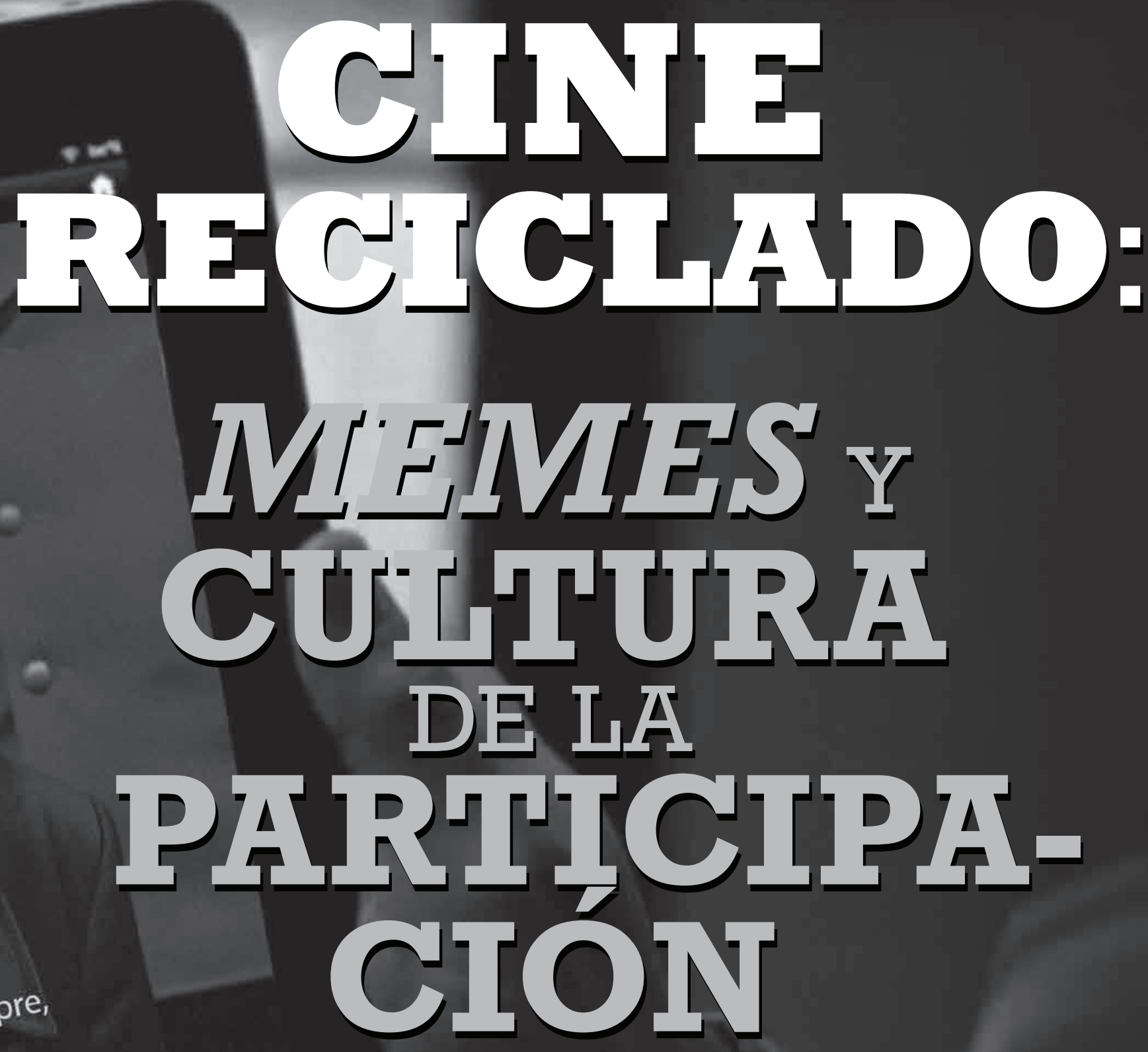

Los memes se han convertido en parte del ADN del espacio virtual por el que navegamos día a día. A través de ellos, el espectador abandona su posición pasiva y adopta una mucho más activa como prosumidor. Existen posibilidades infinitas, solo sujetas a la creatividad del usuario, para modificar y manipular los relatos fílmicos en la web.

Julio César Mateus y Enric Rodon* 
Otra de las claves para interpretar los memes es el de las narrativas transmedia. El concepto no solo define los universos ficcionales que se expanden estratégicamente en varios medios (el cómic que continúa su ficción en la pantalla es un caso); sino también al contenido generado por los usuarios; muchos de los cuales ya no se conforman con organizarse en grupos de fans, sino que convierten las películas y los personajes en elementos disponibles para su collage creativo. Este acto de reapropiación puede ser respetuoso y analítico, o impertinente y desbocado, apelando al humor y desmontando los componentes fílmicos en clave de parodias.

Añadir subtítulos falsos en alguna escena es apenas uno de los mecanismos de reapropiación. Las taxonomías del video digital incluyen fórmulas tan diversas como el remix, que consiste en utilizar el texto original de las películas para generar nuevos desenlaces: el mashup, que vincula mundos narrativos diferentes, yuxtaponiendo personajes de una trama en otra; el recap, el cual sintetiza argumentos de alguna película o de una saga para resumirlos en pocos minutos. Son técnicas que no admiten clasificaciones rígidas, pues se reinventan todo el tiempo.

Estos mecanismos expresivos que circulan por las redes sociales, provenientes de medios clásicos como el cine o la televisión, sintetizan dos atributos de la cultura popular contemporánea. Primero, los sistemas de representación posmoderna (o nuevos simulacros, como diría Baudrillard); y segundo, la "cultura participativa" que refería Jenkins, donde los prosumidores son activos partícipes de las narrativas que les apasionan. Ya no estamos frente al receptor que se conmueve viendo el final de un filme, sino el que quiere proponer uno nuevo. Y lo hace.

\section{Cuadros vivientes}

YouTube es la industria de los memes en movimiento, como el de "Hitler", mientras Facebook y otros foros virtuales son la fábrica de los memes $f i$ jos. Imágenes que registran un gesto particular o una frase memorable de alguna película que los usuarios transforman en iconos que se esparcirán por la red como poderosos virus.

El cine es cantera inagotable de $\mathrm{fra}$ mes reciclados y resignificados a vo- luntad de los prosumidores. Una imagen vale más que mil palabras, pero si van juntas, mejor. En la gramática de la convergencia de medios cualquier recurso comunicativo es complementario y la lógica intertextual de las redes virtuales consigue en los memes cualidades expresivas insustituibles.

El capitán Picard (Patrick Stewart), por ejemplo, devino en un icono de la indignación universal. Su meme inmortaliza un gesto particular de la tercera temporada de Star Trek: The next generation, en que se lleva la mano a la cara luego de que el temperamental Q le pidiera subir a bordo del Enterprise. En versión de algún usuario, sin embargo, el gesto también sirve para representar el sentimiento de muchos republicanos estadounidenses sobre el incremento de impuestos para los contribuyentes ricos que propuso el presidente Obama (ver imagen 1).

Haber visto la película no es un requerimiento para comprender estos memes. La imagen se explica a sí misma, independientemente del contexto original del que surge. La exacta gesticulación es, casi siempre, irreemplazable en el plano verbal, por lo que se convierte en un elemento valioso como resumen de sensaciones. No tengo que escribir la idea a transmitir, pues ya se ve. La imagen de Willy Wonka (Gene Wilder), el famoso dueño de la mágica fábrica de chocolates (Willy Wonka y la fábrica de chocolate, 1971), es una muestra magistral de la riqueza textual del gesto (ver imagen 2).

También se puede proponer el gesto con un valor escrito adjunto, como el caso del meme de Severus Snape (Alan Rickman), el inquietante profesor mago en Harry Potter y las reliquias de la muerte, invadido por una combinación de confusión y miedo frente a un hecho inverosímil (ver imagen 3). A la gráfica manifestación gestual, el potente meme añade la frase "Dafuq", que es la constricción de la frase "What the fuck!” (“iqué carajo!”), generando un tándem texto-imagen recurrente en las conversaciones en línea.

Pero la sustancia de los memes también puede situarse en la frase verbal. Aquí la imagen es, más bien, un complemento que potencia el mensaje. Sucede con "You don't say" ("no me digas"), típico recurso del sarcasmo anglosajón para expresar obviedad. En El beso del vampiro (1988), Nicholas Cage interpreta a un agente literario en decadencia que enloquece al creer que se está convirtiendo en un vampiro. La expresión facial de este meme nace en la escena donde el personaje de Cage atormenta a su secretaria y deviene en parte del repertorio icónico de las redes virtuales (ver imagen 4).

Otros memes surgen a partir de suma de la frase y la imagen en su contexto original. Como "One does not simply walk into Mordor" ("uno no entra tan simplemente a Mordor"), inspirada en la adaptación de Peter Jackson El señor de los anillos: La comunidad del anillo. La escena memetizada ocurre cuando el Concilio de Elrond revela que un anillo maligno debe ser destruido y la única manera de hacerlo es arrojándolo al fuego del Monte Doom, un volcán situado en Mordor. Con esta frase, Boromir (Sean Bean) señala la dificultad del reto que supone la aventura. En este caso no existe una descontextualización ni de la gestualidad ni del texto, pero este último será modificado a placer del creador del meme para expresar cierta dificultad, es decir, lo mismo que Boromir, pero en otro contexto (ver imagen 5).

Similar suerte tiene "Conspiracy Keanu”, un meme inspirado en la escena donde Keanu Reeves dibuja una semblante asustado, en la comedia Bill and Ted's excellent adventure (1989), y que usa para formular conjeturas paranoicas y preguntas afilosóficas absurdas. En este caso, la cara que delata paranoia articula el mensaje (ver imagen 6).

\section{¿Contener o comprometer?}

Desde esta perspectiva, el cine se reinventa con un tono más ecológico. Reciclar y remezclar son moneda corriente de la cotidianidad interactiva, facilitada por los dispositivos digitales.

La imagen intocable de las salas de proyección convive hoy con prácticas caseras de edición y posproducción que la hacen maleable. Bruno Ganz, en la red, se atiene a un guión reticular, desconocido e inagotable, abierto y recreado por cualquiera ad infinitum. La escena es repetida hasta la saciedad, pero resulta novedosa como meme, pues su éxito está en "lo que le hacen decir".

En tiempos de pugnas políticas y comerciales por los derechos de autor 
(copyfight), la productora de la película que protagoniza Ganz, Constantin Films, inició tratos con YouTube para prohibir el uso de la famosa escena (como si los memes no pudieran ser copiados y subidos en otros servidores, precisamente por su cualidad viral). Aunque Google canceló por unos días la circulación de los videos, el tema se estancó. Esta actitud, sin embargo, parece confirmar que la industria cinematográfica no está preparada para los escenarios digitales. Peor, que sigue anquilosada en la idea melancólica del espectador pasivo.

Puede enfrentar la situación de dos formas. Una reactiva, generando políticas punitivas como las actuales advertencias que prohíben y sancionan el uso de sus imágenes por infringir derechos de autor. O una proactiva, por el contrario, que apele a la creatividad y aliente al usuario a comprometerse con el producto. El caso emblema es el de Star wars uncut, un remake de The star wars episode IV: A new hope realizada por cientos de usuarios de todo el mundo a partir de fragmentos de la película original dispuestos en la página web <www.starwarsuncut.com $>$. La cinta, además, logró ganar un Emmy el 2010 en la estrenada categoría "mejor medio interactivo en internet”.

Aun con una actitud más favorable hacia la interacción, nada garantiza el uso "responsable" del producto. Siendo aquella de Hitler una escena históricamente sensible, se le preguntó a Oliver Hirschbiegel, director de $L a$ caída, por su opinión. Dijo que no le molestaba en absoluto y que incluso se divertía viendo muchas de las parodias que se hacían a partir del filme. "Si tan solo tuviera más regalías por eso, estaría aún más feliz”, concluyó. ${ }^{2}$ Quizá no falte mucho para que la industria del cine vea en los memes, más que un inquilino molesto, una forma de expansión comercial y creativa.

\section{Referencias}

Scolari, C. (2013). Narrativas transmedia. Cuando todos los medios cuentan. Barcelona: Deusto.

Shifman, L. (2012). "An anatomy of a YouTube meme". New Media \& Society 14 (2), 187-203.

\section{${ }^{1}$ Entrevista a Ganz en YouTube:}

<http://www.youtube.com/watch?v=4YLqC3DIgjY>

${ }^{2}$ Rosenblum, E. (2010). "The director of Downfall Speaks out on All Those Angry YouTube Hitlers". Vulture.com. (Consulta: 19 de enero del 2013). <http://www.vulture.com/2010/01/the_director_of_ downfall_on_al.html>

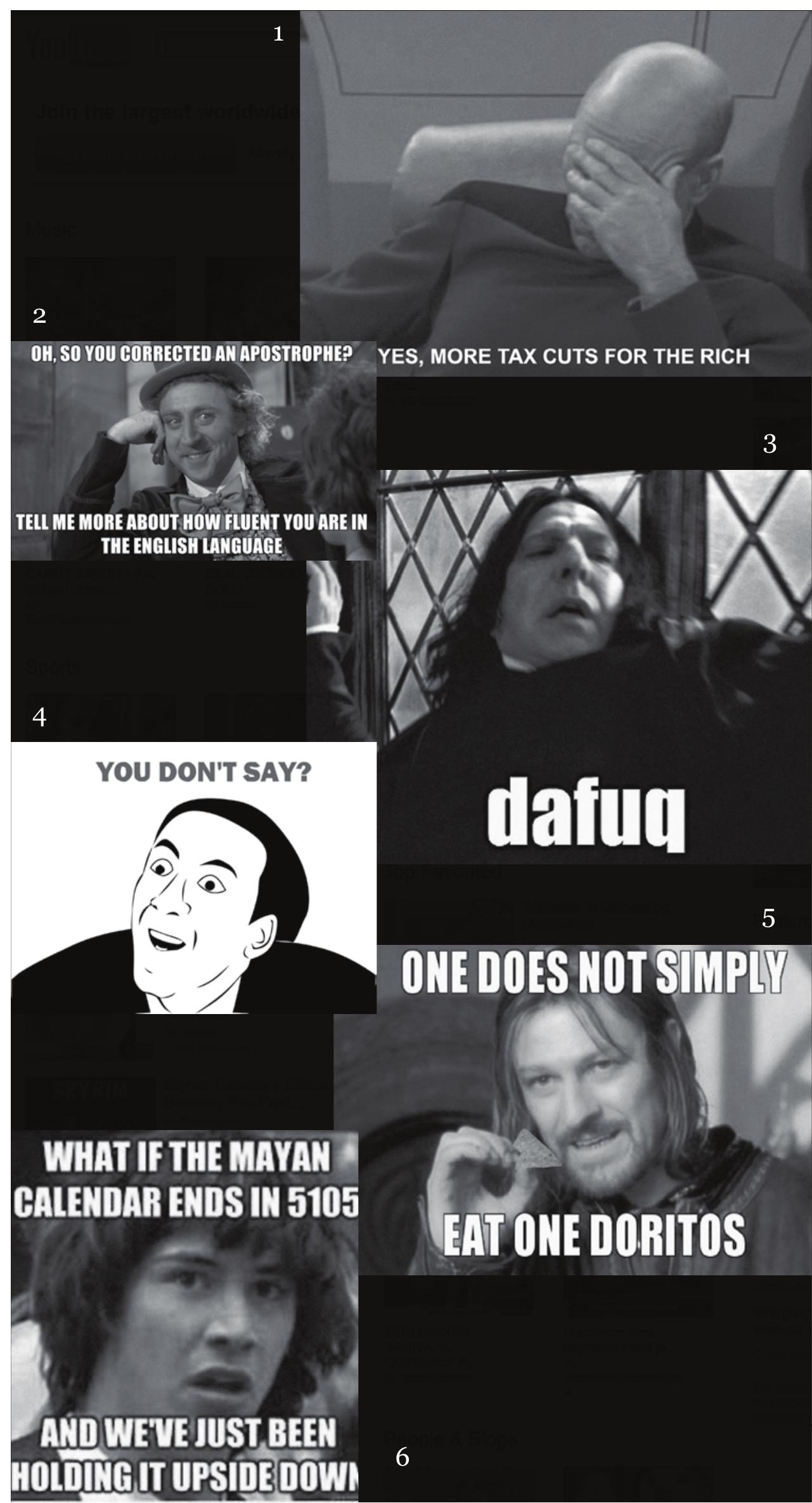

